\title{
ANALISIS PROSES KOMPOSTING PADA PENGELOLAAN SAMPAH BERBASIS MASYARAKAT SKALA KAWASAN (STUDI KASUS DI KOTA DEPOK)
}

\section{Composting Process Analysis on Garbage Treatment Based on the Community Area Scale (Case Studies in Depok)}

\author{
Firman L. Sahwan \\ Pusat Teknologi Lingkungan \\ Badan Pengkajian dan Penerapan Teknologi (BPPT), \\ Jalan M.H. Thamrin No. 8 Jakarta 10340 \\ Email : firman.sahwan@bppt.go.id
}

Diterima : 20 April 2012; Revisi : 27 April 2012; Disetujui : 12 Mei 2012

\begin{abstract}
With waste generation of 4,265 m3 per day and limited current landfill field (TPA), Depok City Government has been implemented district scale of community-based waste management program through the development and management of Waste Processing Units (UPS). That efforts become the spearheading of waste reduction program. The successor issues in the management ofUPS, will be examined using composting as a process parameter analysis. The research concludes: Potential production of compost produced by UPS is quite high which is 27.57 tons per day. At the same time, the potential oforganic waste that can be reduced was $213.5 \mathrm{~m} 3$ per day, equivalent to $5 \%$ of waste generation perdayin the city of Depok. However, compared to its potential, the existing compost production is only 5,099 tonnes perday and existing organic waste processed is $40.85 \mathrm{~m} 3$ pe rday, which is equivalent to $20 \%$ of the existing potential. Hence, the existing compost productionis still can be improved, through the efforts of optimizing the potential of UPS. Until now, there is no independent UPS. Community participation is still limited only to efforts to bring and collect garbage,aside from being the labor and management coordinatorat UPS.
\end{abstract}

Keywords: community-based waste management district scale, waste management units, composting, community participation.

\begin{abstract}
Abstrak
Dengan timbulan sampah sebesar 4.265 m3per hari, serta keterbatasan lahan Tempat Pemrosesan Akhir (TPA) sampah yang dimiliki, membuat Pemkot Depok melaksanakan program pengelolaan sampah berbasis masyarakatskala kawasan, melalui pembangunan dan pengelolaan Unit Pengolahan Sampah (UPS). Upaya tersebut dijadikan ujung tombak program pengurangan sampah. Keberhasilan ataupun kendala dalam pengelolaan UPS, akan dikaji dengan menggunakan proses komposting sebagai parameter analisis. Hasil penelitian menyimpulkan: Potensi produksi kompos yang dihasilkan UPS cukup tinggi yaitu 27,57 ton per hari. Begitu pula potensi sampah organik yang dapat dikurangi sebesar 213,5 m3per hari, setara dengan 5\% timbulan sampah per hari di kota Depok. Namun, dibandingkan dengan potensinya, produksi kompos eksisting sebesar 5,099 ton per hari dan eksisting sampah organik terolah sebanyak 40,85 m3per hari,baru setara dengan $20 \%$ dari potensi yang ada. Untuk itu, produksi kompos eksisting masih terbuka untuk ditingkatkan, melalui upaya optimalisasi potensi UPS. Sampai saat ini belum ada UPS yang sudah mandiri. Partisipasi masyarakat masih terbatas pada upaya untuk membawa dan mengumpulkan sampah, selain menjadi tenaga kerja dan koordinator pengelola di UPS.
\end{abstract}

Kata kunci: Pengelolaan sampah berbasis masyarakat skala kawasan, unit pengelolaan sampah, komposting, partisipasi masyarakat. 


\section{PENDAHULUAN}

Meningkatnya jumlah penduduk dan taraf hidup masyarakat perkotaan telah meningkatkan jumlah timbulan sampah dan karakteristiknya. Kondisi tersebut memperberat beban penanganan sampah, selain dapat menyebabkan pencemaran lingkungan bila tidak diikuti dengan pengelolaan sampah yang memadai. Upaya penanggulangan yang dapat dilakukan adalah melibatkan peran serta masyarakat, serta meningkatkan upaya pendauran ulang sampah (salah satunya adalah komposting) pada kawasan-kawasan tertentu. Konsep tersebut dikenal dengan pengelolaan sampah berbasis masyarakat skala kawasan.

Pengelolaan sampah adalah kegiatan yang sistematis, menyeluruh, dan berkesinambungan yang meliputi pengurangan dan penanganan sampah[1,2]. Pengurangan sampah meliputi kegiatan: pembatasan timbulan sampah; pendauran ulang sampah; dan/atau pemanfaatan kembalisampah. Sedangkan penanganan sampah meliputi kegiatan: pemilahan; pengumpulan; pengangkutan; pengolahan; dan pemrosesan akhir sampah. Posisi komposting pada konsep pengelolaan sampah tersebut terletak pada bagian proses pendauran ulang dan pengolahan sampah.

Pengelolaan sampah berbasis masyarakat (PSBM) skala kawasan, merupakan kombinasi dari 2 (dua) konsep pengelolaan sampah yaitu PSBM dan pengelolaan sampah skala kawasan.Konsep PSBM merupakan suatu pendekatan pengelolaan sampah yang didasarkan pada kebutuhan dan permintaan masyarakat, direncanakan, dilaksanakan (jika memungkinkan), dikendalikan dan dievaluasi bersama masyarakat[3]. Kalau disederhanakan, PSBM adalah sistem penanganan sampah yang direncanakan, disusun, dioperasikan, dikelola dan dimiliki oleh masyarakat[4]. Dalam pengertian tersebut, pemeran utama dalam pengelolaan sampah adalah masyarakat. Pemerintah dan lembaga lainnya sebagai motivator dan fasilitator. Ada juga yang menyebut dengan sistem pengolahan sampah berbasis masyarakat[5].Sedangkan pengelolaan sampah skala kawasan merupakan kegiatan pengelolaan sampah skala komunal untuk melayani sebagian atau keseluruhan sampah yang ada dalam area pengelola kawasan berada, misalnya RT, RW, Kelurahan atau lainnya[6].Peran aktif pengelola kota (pengelola persampahan) sangat menentukan, agar sistem pengelolaan tingkat kawasan ini tetap merupakan bagian yang tak terpisahkan dari sistem pengelolaan sampah kota secara menyeluruh. Oleh karena itu adanya kerjasama yang erat antara masyarakat dan pengelola kota menjadi sangat penting untuk mendukung keberhasilan kegiatan PSBM skala kawasan.
Komposting memiliki peran penting dalam upaya pendauran ulang sampah, karena kemampuannya mengubah sampah organik menjadi pupuk organik kompos. Tingginya prosentase bahan organik pada sampah kota $(70 \%)[7]$, menjadikan sampah kota sangat prospektif untuk dijadikan kompos. Hasil analisis finansial dan eksternalitas menyimpulkan bahwa desentralisasi komposting, lebih efisien daripada sentralisasi komposting[8]. Penelitian tersebut mendukung proses pembuatan kompos skala kawasan. Dengan memanfaatkan sampah menjadi kompos skala kawasan, maka jumlah sampah yang dibuang ke TPA menjadi lebih sedikit, sehingga biaya transportasi sampah menjadi lebih ringan dan umur TPA menjadi lebih panjang.

Kota Depok dengan luas wilayah 20.029 ha, jumlah penduduk 1.470 .002 jiwa, jumlah timbulan sampah 2,65 liter/orang/hari, telah menghasilkan total timbulan sampah per hari sebesar $4.265 \mathrm{m3}$, dengan kandungan organik sebesar 72,97\%[9]. Tingginya timbulan sampah, serta keterbatasan lahan TPA yang dimiliki, membuat Pemkot Depok melaksanakan program pengelolaan sampah berbasis masyarakat skala kawasan melalui pembangunan dan operasionalisasi Unit Pengolahan Sampah (UPS)[10]. Tujuan utamanya adalah mengomposkan sampah organik dari kawasan permukiman, selain mengumpulkan sampah anorganik yang bernilai ekonomis. Upaya tersebut dijadikan ujung tombak pengurangan sampah di Kota Depok. Keberhasilan ataupun kendala yang dihadapi dalam pengelolaan UPS, akan dikaji dengan menggunakan proses komposting sebagai parameter analisis.

Komposting merupakan proses dekomposisi bahan organik (sampah organik) secara biologis dalam kondisi aerobik dan termofilik terkendali menjadi produk stabil seperti humus, yaitu kompos $[10,11,12,13]$. Kompos merupakan salah satu jenis pupuk organik.Pupuk organik adalah pupuk yang berasal dari tumbuhan mati, kotoran hewan dan/atau bagian hewan dan/atau limbah organik lainnya yang telah melalui proses rekayasa, berbentuk padat atau cair, dapat diperkaya dengan bahan mineral dan/atau mikroba, yang bermanfaat untuk meningkatkan kandungan hara dan bahan organik tanah, serta memperbaiki sifat fisik, kimia dan biologi tanah [14]. Dengan difinisi tersebut, pupuk kompos merupakan pupuk organik yang sengaja dibuat melalui suatu proses yang terkendali yang disebut pengomposan, untuk menghasilkan pupuk organik yang berkualitas.

Teknologi komposting skala kawasan yang paling sesuai untuk kondisi Indonesia, berdasarkan kondisi iklim, ekonomi dan sosial budaya adalah sistem dengan tumpukan terbuka (open windrow) atau modifikasinya [13]. Hal tersebut telah 
diuji dengan analisis multikriteria pengambilan keputusan dalam seleksi teknologi komposting[8].

Parameter utama yang berpengaruh terhadap berlangsungnya proses komposting yang baik adalah rasio $\mathrm{C} / \mathrm{N}$, kadar air, konsentrasi oksigen, ukuran partikel, suhu, $\mathrm{pH}$ dan ketersediaan konsorsium mikroorganisme[10,11,12,13].

Perbandingan karbon dan nitrogen (rasio $\mathrm{C} / \mathrm{N}$ ) ideal untuk suatu proses komposting adalah antara 20 sampai 40 atau optimalnya 30 karbon berbanding dengan 1 (satu) nitrogen[10,11,12,13]. Sampah kota memiliki rasio C/N 30-40 berbanding 1(satu), sehingga cukup optimal untuk suatu proses komposting. Begitu pula kadar air sampah kota yang berkisar antara $44 \%, 81 \%$ $-56 \%, 58 \%$ untuk sampah pemukiman dan pasar di DKI Jakarta[14] akan mendukung kebutuhan kadar air optimal proses komposting yang 50 $\% \quad-60 \%[10,11,12,13]$. Apabila dalam proses komposting dirasakan kekurangan kadar air, maka dapat dilakukan penyiraman agar kondisi kadar air optimal selalu dapat dipertahankan.

Proses pengomposan merupakan proses aerob. Paling sedikit 50\% konsentrasi oksigen yang ada di udara dapat mencapai seluruh bagian materi yang dikomposkan[10,11,12,13]. Untuk itu aerasi dari materi yang dikomposkan harus baik, dan hal tersebut bisa dicapai apabila ukuran bahan baku berkisar antara $2,5 \mathrm{~cm}-7,5 \mathrm{~cm}[10,11,12,13]$. Secara umum, sampah kota sudah memiliki ukuran tersebut.

Dengan bahan baku yang baik dan ditunjang oleh proses yang benar, maka suhu dari materi sampahyang dikomposkanakannaikhinggasekitar 700C. Begitu pula dengan $\mathrm{pH}$ akan berada pada rentang $\mathrm{pH}$ netral (7). Kalau itu yang terjadi, maka proses komposting dapat dikatakan berjalan baik

Proses komposting merupakan proses dekomposisi secara biologis oleh konsorsium mikroorganisme. Oleh karena itu konsorsium mikroba merupakan mesin utama dalam proses dekomposisi, sehingga keberadaannya mutlak diperlukan. Keberadaankonsorsiummikrobadalam sampah kota sudah berlimpah[12,13], sehingga tidak perlu penambahan mikroba khusus dari luar.

Berdasarkan hal tersebut di atas terlihat bahwa sifat dan karakter sampah kota cukup ideal untuk suatu proses pengomposan. Apabila proses kompostingnya benar, akan dihasilkan kompos dengan kualitas baik seperti yang telah dihasilkan di Jakarta[17], Probolinggo[18], Buleleng[19] dan lain-lain.

Kompos yang dihasilkan akan membantu mengatasi permasalahan rendahnya kandungan bahan organik tanah. Tanah umumnya mengandung $2 \%-10 \%$ bahan organik. Walaupun persentasenya sedikit, namun peranannya sangat penting terhadap kesuburan tanah dan nutrisi tanaman[20], sehingga bahan organik disebut sebagai nyawanya tanah[21]. Kondisi kandungan C-organik tanah saat ini $73 \%$ tergolong rendah $(<2 \%), 23 \%$ tergolong sedang (2\% $-3 \%$ ) dan hanya $4 \%$ yang tergolong tinggi $(>3 \%)[22]$. Secara lebih spesifik, dinyatakan bahwa $65 \%$ dari 7,9 juta hektar lahan sawah di Indonesia memiliki kandungan bahan organik rendah sampai sangat rendah (C-organik $<2 \%$ ) [23]. Penelitian ini dilakukan dengan tujuan untuk menganalisis proses komposting, menghitung kapasitas produksi, produksi eksisting dan potensi pengurangan sampah yang dapat disumbangkan dari UPS yang ada di Kota Depok, dan mengetahui peran serta masyarakat dalam pengelolaan UPS.

\section{BAHAN DAN METODE}

\subsection{Tempat dan Waktu Penelitian}

Penelitian ini dilakukan di UPS-UPS yang tersebar di wilayah Kota Depok, pada Bulan Juni dan Nopember 2011.

\subsection{Cara Penelitian}

Penelitian ini dilakukan dengan cara:

- Melakukan survey ke seluruh UPS yang tersebar di wilayah Kota Depok.

- Melakukan wawancara dengan pengelola dan tenaga kerja, berdasarkan kuesioner.

- Menginventarisir sarana dan prasarana pendukung.

- Mengukur dan menghitung luasan UPS yang dijadikan ruang untuk proses komposting, sebagai dasar untuk menghitung kapasitas produksi kompos.

- Mengukur dan menghitung jumlah tumpukan sampah yang sedang diproses menjadi kompos, sebagai dasar menghitung produksi eksisting kompos.

- Melakukan analisis data.

\subsection{Cara Menghitung Kapasitas Produksi dan Produksi Kompos Eksisting [24]}

Kapasitas produksi dihitung berdasarkan luas composting hall, yaitu ruangan yang digunakan untuk mengkomposkan sampah organik. Sedangkan luas composting hall diperoleh berdasarkan hasil pengukuran di lapangan.

Perhitungan kapasitas produksi, didasarkan atas beberapa asumsi sebagai berikut:

- Sampah organik jumlahnya $70 \%[7,9]$ dari keseluruhan sampah campuran yang belum terpilah.

- Proses komposting menggunakan sistem windrow bergulir[18] dimana setiap $1 \mathrm{~m} 3$ sampah yang ditumpuk, mengokupasi lahan seluas 1,48 m2.

- Jarak antar tumpukan 0,8 m. 
- Lama proses komposting 7 minggu (49 hari).

- Penyusutan pada minggu ke-2 adalah $30 \%$, minggu ke-3, 50\%, minggu ke- $4,60 \%$, minggu ke-5, $70 \%$, minggu ke- $6,75 \%$ dan minggu ke-7, 75\%. Berat jenis kompos 0,5.

Dengan menggunakan asumsi tersebut, akan diperoleh hubungan antara jumlah sampah campuran (m3 per hari), jumlah sampah organik (m3 per hari), luas composting hall (m2), dan kapasitas produksi (ton/hari). Misalnya kapasitas produksi 1 ton/hari, dibutuhkan luas composting hall $300 \mathrm{~m} 2$, sampah organik $8 \mathrm{~m} 3$ per hari dan sampah campuran 11,43 m3 per hari.

Sedangkan produksi kompos eksisting, dihitung berdasarkan keseluruhan volume tumpukan sampah yang dikomposkan. Volume tumpukan diperoleh berdasarkan hasil pengukuran di lapangan, dan masing-masing tumpukan dicatat umurnya dalam satuan minggu. Dalam perhitungan volume total tumpukan, masing-masing tumpukan dikalikan dengan faktor penyusutan.

Volumekompos $=25 \%-100 \%$ volumetumpukan:

- Volume tumpukan minggu 1 dikalikan $25 \%$

- Volume tumpukan minggu 2 dikalikan $36 \%$

- Volume tumpukan minggu 3 dikalikan $50 \%$

- Volume tumpukan minggu 4 dikalikan $63 \%$

- Volume tumpukan minggu 5 dikalikan $83 \%$

- Volume tumpukan minggu 6 dikalikan $100 \%$

- Volume tumpukan minggu 7 dikalikan $100 \%$

Asumsi proses pengomposan di kota Depok selama 6 bulan. Berat kompos $=0,5$ volume produk kompos.

\section{HASIL DAN PEMBAHASAN}

\subsection{Unit Pengolahan Sampah (UPS) dan Pros- es Komposting}

Unit Pengolahan Sampah yang disurvey ada 21 plant, yang merupakan UPS yang telah dibangun oleh Pemkot Depok, yaitu: UPS Jalan Jawa, UPS Merdeka 2, UPS Sadewa, UPS Sukatani, UPS Mekarsari, UPS Cilangkap, UPS Permata Regency, UPS Bojong Pondok Terong, UPS Bulak Timur, UPS Lama TPA Cipayung, UPS Hanggar 3 TPA Cipayung, UPS Hanggar 1 TPA Cipayung, UPS Hanggar 2 TPA Cipayung, UPS Hanggar 4 TPA Cipayung, UPS Bojongsari, UPS Meruyung, UPS Grogol, UPS Limo Kampung Sasak, UPS Pangkalan Jati, UPS Gunadarma dan UPS Pasar Cisalak. Dari 22 UPS tersebut, ada 2 UPS yang tidak lagi difungsikan sebagai tempat proses pengomposan yaitu: UPS Lama TPA Cipayung, dan UPS Sadewa. Jumlah tersebut merupakan jumlah terbanyak yang ada di Indonesia, dan sangat potensial untuk dijadikan ujung tombak pengurangan sampah.

Sarana dan prasarana proses pengomposan di UPS berupa bangunan pengomposan, bangunan kantor, conveyor pemilahan dan mesin pencacah, mesin pencacah dan mesin penyaring kompos. UPS tersebut dibangun dan dikelola oleh Pemkot Depok, termasuk menyediakan tenaga kerja. Masing-masing UPS umumnya dijalankan oleh 14 orang tenaga kerja, termasuk 1 (satu) orang sebagai koordinator.

Untuk menjalankan UPS, pengelola mengikuti tatacara proses komposting yang telah diajarkan oleh Pemkot Depok. Sumber sampah yang merupakan sampah belum terpilah, berasal dari permukiman dimana UPS berada, kecuali UPS yang berada di TPA Cipayung dan Pasar Cisalak, sumber sampah berasal dari sampah pasar. Selain proses pengomposan, di dalam UPS

dilakukan juga usaha pengumpulan barang lapak, yaitu sampah anorganik yang laku dijual. Malahan usaha ini terlihat lebih diprioritaskan, dibandingkan dengan upaya untuk membuat kompos.

Adapun tahapan proses pengomposan yang dilakukan adalah sebagai berikut: pemilahan sampah, pencacahan, penumpukan skala besar dengan tanpa pembalikan dan penyiraman (pengomposan pasif), penumpukan skala kecil dengan pembalikan dan penyiraman (pengomposan aktif), penyaringan dan pengemasan. Diagram alir proses komposting di UPS, disajikan pada pada Gambar 1.

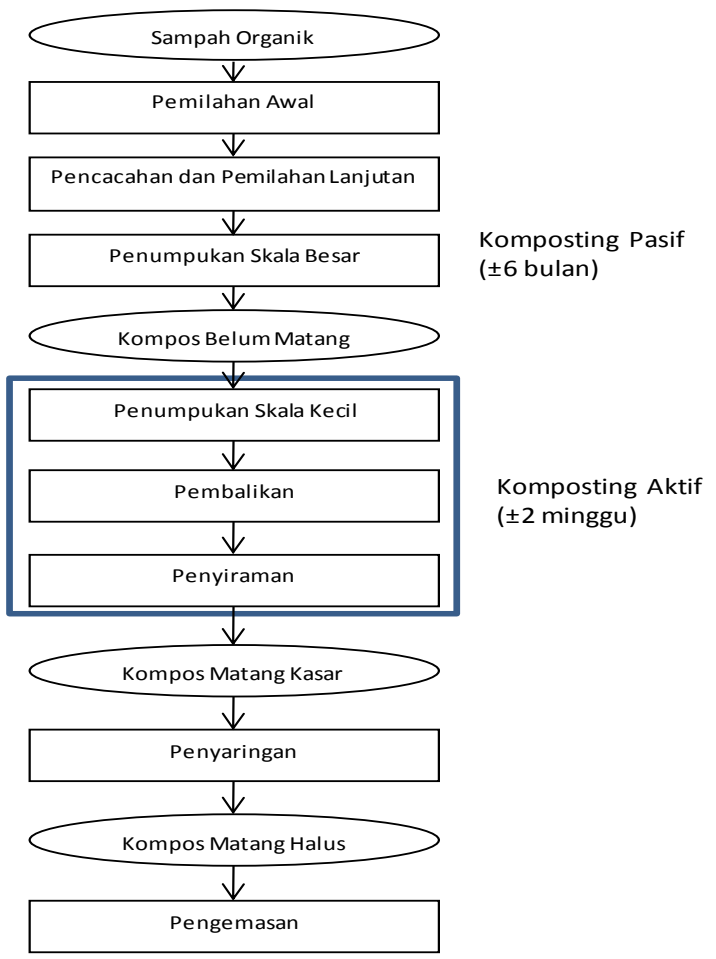

Gambar 1. Diagram alir proses komposting 
Proses pengomposan yang terjadi di UPS perlu dianalisis, khususnya untuk proses komposting pasif dan proses komposting aktif. Proses komposting pasif dilakukan sebelum proses komposting aktif, yaitu dengan cara menumpuk sampah organik yang telah dipilah dan dicacah menjadi tumpukan besar, dengan tanpa diikuti oleh proses pengadukan dan penyiraman. Proses ini dinamakan dengan proses pengomposan pasif, karena faktor utama yang dibutuhkan untuk suatu proses pengomposan aktif seperti: kecukupan oksigen dan kebutuhan air untuk suatu proses metabolisme mikroba yang optimal tidak dapat dipenuhi. Untuk itu, proses degradasi atau proses penguraian materi organik berlangsung lama. Biasanya materi organik berada dalam tumpukan besar kurang lebih sekitar 6 bulan, bahkan lebih, tergantung dari adanya permintaan kompos.

Begitu ada permintaan kompos, maka materi organik yang berada dalam tumpukan besar, sebagian dipanen (diambil) untuk kemudian dibentuk menjadi tumpukan kecil dengan ukuran sekitar $2 \mathrm{~m} \times 2 \mathrm{~m} \times 1 \mathrm{~m}$. Di tumpukan kecil ini, materi organik diaduk untuk memberikan kecukupan oksigen, dan disiram untuk memenuhi kebutuhan air. Proses yang terjadi dinamakan dengan pengomposan aktif, dan berlangsung selama 2-3 minggu.

Proses komposting biasanya diawali dengan fase aktif selama 2-4 minggu [25, 26] , yang biasanya ditandai dengan terciptanya suhu yang tingggi (bisa mencapai $700 \mathrm{C}$ ) dan penurunan volume materi organik yang tinggi (sekitar $50 \%$ dan bahkan lebih). Setelah fase aktif ini maka aktivitas mikroorganisme menurun, sehingga disebut dengan fase pasif atau fase pematangan[25,26].

Proses komposting di UPS, akan lebih baik dan lebih efektif kalau mengikuti kaidah-kaidah proses komposting, yaitu proses aktif yang diikuti dengan proses pematangan (pasif). Caranya dengan menukar alur proses antara penumpukan skala besar dan penumpukan skala kecil. Proses penumpukan skala kecil yang di dalamnya terdapat proses pengadukan dan penyiraman dilakukan terlebih dahulu sebelum penumpukan skala besar. Proses penumpukan sekala kecil dapat dilakukan dalam waktu 2-3 minggu, dan dianggap sebagai proses pengomposan aktif. Sedangkan proses penumpukan sekala besar yang tanpa pengadukan dan penyiraman, dianggap sebagai fase pematangan atau pengomposan pasif. Sebaiknya tumpukan sekala besar tidak dibuat dalam satu tumpukan. Minimal ada 2 atau 3 tumpukan besar, untuk memudahkan memilih tumpukan yang sudah matang dan dapat dipanen.

\subsection{Potensi Produksi Kompos, Produksi Kompos Eksisting dan Pengurangan Sampah}

Dari 21 Unit Pengolahan Sampah (UPS) yang ada di Kota Depok, dapat dihitung dan diketahui: luas komposting hall, potensi produksi kompos, potensi sampah organik yang dapat terolah, produksi kompos eksisting serta eksisting sampah organik yang terolah. Data hasil perhitungan disajikan pada Tabel 1.

Majemuk NPK dan Pupuk Organik, Seminar Nasional Peranan Pupuk NPK dan Organik dalam Meningkatkan Produksi dan Swasembada Beras Berkelanjutan, Badan Penelitian dan Pengembangan Pertanian Berdasarkan data pada Tabel 1, terlihat bahwa kemampuan (potensi) UPS yang ada di Kota Depok untuk memproduksi kompos cukup tinggi yaitu 27,57 ton per hari. Untuk menghasilkan kompos sebanyak tersebut, dibutuhkan input sampah organik sebesar 213,5 m3perhari,yangsamadengan $5 \%$ timbulansampah di kota Depok yang dapat dikurangi setiap hari.

Namun, potensi UPS yang ada belum dimanfaatkan secara maksimal. Hal ini terlihat dari produksi kompos eksisting yang cuma 5,099 ton per hari dan eksisting sampah organik terolah sebesar 40,85 m3 per hari, ternyata baru 20\% dari kemampuan (potensi) yang ada. Untuk itu diperlukan upaya untuk lebih mengoptimalkan potensi yang ada antara lain: lebih mengefektifkan tenaga kerja yang ada, lebih mengefisienkan penggunaan /pengaturan ruang UPS, merubah alur proses penumpukan besar dan kecil, serta mengikuti kaidah-kaidah proses komposting.

\subsection{Peran Serta Masyarakat}

Konsep pembangunan UPS adalah memaksimalkan potensi masyarakat untuk dapat berperan serta dalam pengelolaan sampah [9, 10], dalam kawasan permukiman tertentu, yaitu kawasan kompleks perumahan, kawasan perumahan non kompleks dan kawasan perumahan kumuh/bantaran sungai [10]. Konsep tersebut dikenal dengan pengelolaan sampah berbasis masyarakat $[4,5]$ skala kawasan. Salah satu kriteria kelayakan lokasi UPS adalah adanya kelompok swadaya masyarakat yang sudah eksis atau kegiatan serupa yang berbasis masyarakat[10]. Pada tahap awal managerial di UPS, berada dibawah koordinasi Pemkot Depok, termasuk gaji tenaga kerja. Namun kedepan, diharapkan UPS yang ada dapat mandiri.

Keterlibatan masyarakat saat ini terutama dalam upaya membawa dan mengumpulkan sampah di UPS dibawah koordinasi RT/RW setempat. Keterlibatan yang lain adalah sebagai tenaga kerja dan koordinator pengelola di UPS. Sampai saat ini belum ada UPS yang sudah mandiri, walaupun sebelumnya dinyatakan akan ada UPS yang akan mandiri. Salah satu penyebab dari sulitnya UPS yang ada untuk 
mandiri adalah karena sulitnya memasarkan produk kompos yang dihasilkan. Untuk itu perlu adanya terobosan untuk dapat mempermudah pemasaran kompos yang ada, misalnya seluruh kebutuhan pupuk organik di lingkungan Pemkot Depok harus dipasok dari UPS yang ada.

Tabel 1. Potensi dan Eksisting Produksi Kompos, serta Potensi dan Eksisting Sampah Organik Terolah di Kota Depok.

\begin{tabular}{|c|c|c|c|c|c|}
\hline Nama UPS & $\begin{array}{l}\text { Luas } \\
\text { Kompos- } \\
\text { ting Hall } \\
\left(\mathrm{m}^{2}\right)\end{array}$ & $\begin{array}{l}\text { Potensi } \\
\text { Produksi } \\
\text { Kompos } \\
\text { (ton/hari) }\end{array}$ & $\begin{array}{l}\text { Potensi } \\
\text { Sampah } \\
\text { Organik } \\
\text { Terolah } \\
\left(\mathrm{m}^{3} / \text { hari) }\right.\end{array}$ & $\begin{array}{l}\text { Produksi } \\
\text { Kompos } \\
\text { Eksisting } \\
\text { (ton/hari) }\end{array}$ & $\begin{array}{c}\text { Eksisting } \\
\text { Sampah } \\
\text { Organik } \\
\text { Terolah } \\
\left(\mathrm{m}^{3} / \text { hari) }\right.\end{array}$ \\
\hline Merdeka 2 & 412,5 & 1,34 & 10,75 & 0,082 & 0,66 \\
\hline Sukatani & 502,5 & 1,63 & 13,00 & 0,225 & 1,80 \\
\hline Mekarsari & 298,5 & 1,00 & 8,00 & 0,375 & 3,00 \\
\hline Cilangkap; & 462,5 & 1,50 & 12,00 & 0,200 & 1,60 \\
\hline Permata Regency & 334,5 & 1,95 & 8,75 & 0,071 & 0,57 \\
\hline Bojong Pondok Terong & 282,5 & 0,94 & 7,50 & 0,339 & 2,72 \\
\hline Bulak Timur & 262,5 & 0,88 & 7,00 & 0,104 & 0,84 \\
\hline TPA Lama & 78,0 & 0,31 & 2,50 & - & - \\
\hline Hanggar 3 TPA & 442,5 & 1,44 & 11,50 & 0,300 & 2,40 \\
\hline Hanggar 1 TPA & 522,5 & 1,69 & 13,50 & 0,031 & 0,25 \\
\hline Hanggar 2 TPA & 487,5 & 1,59 & 12,75 & 0,154 & 1,24 \\
\hline Hanggar 4 TPA & 477,0 & 1,56 & 12,50 & 0,525 & 4,20 \\
\hline Bojongsari & 337,5 & 1,13 & 9,00 & 0,469 & 3,76 \\
\hline Meruyung & 322,5 & 1,06 & 8,50 & 0,297 & 2,38 \\
\hline Grogol & 502,5 & 1,63 & 13,00 & 0,176 & 1,41 \\
\hline Limo Kampung Sasak & 298,5 & 1,00 & 8,00 & 0,389 & 3,12 \\
\hline Pangkalan Jati & 352,5 & 1,16 & 9,25 & 0,715 & 5,72 \\
\hline Guna Dharma & 502,5 & 1,63 & 13,00 & 0,176 & 1,41 \\
\hline Jalan Jawa & 378,0 & 1,25 & 10,00 & 0,062 & 0,50 \\
\hline Sadewa & 212,5 & 0,72 & 5,75 & - & - \\
\hline Pasar Cisalak & 672,0 & 2,16 & 17,25 & 0,408 & 3,27 \\
\hline Jumlah & $8.141,5$ & 27,57 & 213,5 & 5,099 & 40,85 \\
\hline
\end{tabular}

\section{KESIMPULAN}

Berdasarkan hasil penelitian yang telah dilakukan dapat ditarik beberapa kesimpulan sebagai berikut, di antaranya pengelolaan sampah berbasis masyarakat skala kawasan melalui pembangunan dan pengelolaan Unit Pengelolaan Sampah, sangat potensial untuk dijadikan ujung tombak program pengurangan sampah di Kota Depok, dalam rangka mengendalikan permasalahan sampah, khususnya keterbatasan lahan TPA.UPS yang ada sebanyak 21 unit. Sebagian besar masih beroperasi sesuai SOP yang diberikan oleh Pemkot Depok.Potensi produksi kompos dari keseluruhan UPS cukup 
tinggi yaitu sebesar 27,57 ton per hari. Begitu pula potensi sampah organik yang dapat dikurangi sebanyak $213,5 \mathrm{~m} 3$ per hari. Potensi tersebut sama dengan $5 \%$ timbulan sampah di kota Depok. Dibandingkan dengan kapasitasnya, produksi kompos eksisting sebanyak 5,099 ton per hari dan eksisting sampah organik terolah sebesar 40,85 m3 per hari, identik dengan $20 \%$ dari potensi yang ada.Produksi kompos eksisting dari tiap-tiap UPS masih terbuka untuk ditingkatkan, melalui upaya optimalisasi potensi UPS.Sampai saat ini belum ada UPS yang mandiri. Partisipasi masyarakat masih terbatas pada upaya untuk membawa dan mengumpulkan sampah di UPS, selain menjadi tenaga kerja dan koordinator pengelola di UPS.

\section{DAFTAR PUSTAKA}

1. Undang-Undang Republik Indonesia Nomor 18 Tahun 2008 tentang Pengelolaan Sampah.

2. Peraturan Pemerintah Republik Indonesia Nomor 81 Tahun 2012 tentang Pengelolaan Sampah Rumah Tangga dan Sampah Sejenis SampahRumah Tangga.

3. Kelompok Kerja Air Minum dan Penyehatan Lingkungan, 2009. Keterlibatan Masyarakat dalam Pengelolaan Sampah: Suatu Keniscayaan. Laporan Utama Majalah Percik Bulan Mei, Edisi Khusus Pengelolaan Sampah Berbasis Masyarakat.

4. Sidik, U.S. 2009. Implementasi Peran Masyarakat Sesuai UU NO. 18 Tahun 2008. Majalah Percik Bulan Mei, Edisi Khusus Pengelolaan Sampah Berbasis Masyarakat, Pokja AMPL, Jakarta.

5. Yuwono, R, L. Wardhani, U. Ninghadiyati, dan E. Adinugroho, 2008. Pengembangan Sistem Persampahan Berbasis Masyarakat. Pokja AMPL, Jakarta.

6. Damanhuri, E dan T. Padmi, 2010. Pengelolaan Sampah. Program Studi Teknik Lingkungan, Fakultas Teknik Sipil dan Lingkungan, Institut Teknologi Bandung.

7. Kementerian Negara Lingkungan Hidup, 2008. Statistik Persampahan Indonesia Tahun 2008.

8. Wahyono, S., 2012. Metabolisme Pengelolaan Sampah Organik Melalui Teknologi Komposting di Wilayah Internal Perkotaan (Kajian Pengelolaan Sampah Organik pada Tipologi Kota Sedang, Studi Kasus di Kota Probolinggo, Jawa Timur). Ringkasan Disertasi Jenjang Doktor, Program Studi IImu Lingkungan, Program Pascasarjana, Universitas Indonesia, Jakarta.

9. Bappeda Kota Depok, 2008. Rencana Induk Persampahan Kota Depok.

10. Bappeda Kota Depok, 2007. Ringkasan Eksekutif Kajian Pengelolaan Persampahan Kota Depok.

11. Haug, R.T., 1980. Compost Engineering, Principles and Practice, An Arbor Science Publisher Inc., Michigan.

12. Tchobanouglous, G., H. Theisen and S. Vigil, 1993. Integrated Solid Waste Management, Engineering Principles and Management Issues. Mc Graw-Hill Inc., USA.
13. Epstein, E., 1997. The Science of Composting, Technomic Publishing Company Inc., USA.

14. Wahyono, S., F.L. Sahwan dan F. Suryanto, 2003. Menyulap Sampah Menjadi Kompos, Pusat Pengkajian dan Penerapan Teknologi Lingkungan, BPPT, Jakarta.

15. Menteri Pertanian Republik Indonesia, 2011. Peraturan Menteri Pertanian No 70/Permentan/ SR.140/10/2011, Tentang Pupuk Organik, Pupuk Hayati dan Pembenah Tanah. Berita Negara Republik Indonesia Tahun 2009 Nomor 137.

16. Dinas Kebersihan DKI Jakarta, 2005. Laporan Akhir Solid Waste Management for DKI Jakarta, Master Plant Review and Program Development WJEMP Loan 4612-INO/Credit 3519-IND (DKI 3-11).

17. Sahwan, F.L., 2010. Kualitas Produk Kompos dan Karakteristik Proses Pengomposan Sampah Kota Tanpa Pemilahan Awal. Jurnal Teknologi Lingkungan Pusat Teknologi Lingkungan-BPPT, 11(1):79-85.

18. Pusat Teknologi Lingkungan, 2008. Laporan Kegiatan Pemanfaatan Sampah Kota Menjadi Pupuk Organik dengan Teknologi Accelerated Revolver Windrow Composting untuk Ketahanan Pertanian Padi di Probolinggo, BPPT, Jakarta.

19. Sahwan, F.L., S. Wahyono dan F. Suryanto, 2010. Kualitas dan Produksi Pupuk Organik Granul (POG) Sampah Kota Serta Manfaatnya Untuk Mengurangi Pengaruh Emisi Gas Rumah Kaca. Jurnal Teknologi Lingkungan, Pusat Teknologi Lingkungan-BPPT, Edisi Khusus Global Warming: 51-59.

20. Munawar, A., 2011. Kesuburan Tanah dan Nutrisi Tanaman, IPB Press, Bogor.

21. Iswandi, A., 2010. Peranan Pupuk Organik dan Pupuk Hayati dalam Peningkatan Produktivitas Beras Berkelanjutan. Makalah pada Seminar Nasional Peranan Pupuk NPK dan Organik dalam Meningkatkan Produksi dan Swasembada Beras Berkelanjutan. Balai Besar Litbang Sumberdaya Lahan Pertanian, Badan Penelitian dan Pengembangan Pertanian, Kementerian Pertanian, Jakarta.

22. Las, I., 2010. Arah dan Strategi Pengembangan Pupuk, Kementerian Pertanian, Jakarta.

23. Kementerian Pertanian Republik Indonesia, 2010. Pemulihan Kesuburan Tanah pada Lahan Sawah Berkelanjutan. Badan Litbang Pertanian dan Ditjen Tanaman Pangan, Jakarta. Kementerian Pertanian Republik Indonesia, 2010. Pemulihan Kesuburan Tanah pada Lahan Sawah Berkelanjutan. Badan Litbang Pertanian dan Ditjen Tanaman Pangan, Jakarta.

24. Wahyono, S., 2011. Petunjuk Teknis Menghitung Produksi Kompos. Pusat Teknologi Lingkungan -BPPT.

25. Wahyono, S., F.L. Sahwan dan F. Suryanto, 2011. Membuat Pupuk Organik Granul dari Aneka Limbah. PT AgroMedia Pustaka, Jakarta.

26. Wahyono, S., F.L. Sahwan dan F. Suryanto, 2011. Kupas Tuntas Dari A-Z Komposting Sampah Kota Skala Kawasan. PTL-BPPT. 
